\title{
Towards Building an Open Digital Library for Instructional Design that Facilitates Reflective e-Instruction
}

\author{
Mihaela-Monica VLADOIU \\ Department of Informatics, Petroleum-Gas University of Ploiesti \\ Bd. Bucuresti, Nr. 39, Ploiesti, Romania \\ e-mail:mvladoiu@yahoo.com
}

Received: June 2003

\begin{abstract}
Computer-based instruction, online or offline, which we will be referring at as einstruction, provides for the development of new flexible pedagogical frameworks that will offer opportunities for open worldwide lifelong instruction. We claim that these are to be stored in instructional digital libraries in order to be accessible to anyone, anytime, anywhere. While many advances have been made in the creation of digital libraries, there is considerable room both for improving how learning objects are accessed/re-used by educators and learners, and for enhanced support for instruction design and for implementation of sound instructional systems.

We present here our ongoing work that aims to build a core instructional design digital library for reflective, learner-centered, e-instruction and to make it available to its potential users. Firstly, we describe our model for e-instruction design and its support tool. We present further on a construction scheme for storing this evolving model into a digital library, using the services provided by an open digital library service system, OpenDLib, which has been built at ISTI-CNR Pisa, Italy. We have chosen OpenDLib as a "constructor" for our digital library because it has a powerful document model, it is open, dinamically expandable, and open source. Finally, our research plan that approaches instructional design that facilitates reflective, learner-centered, e-instruction is shown.
\end{abstract}

Key words: e-instruction model, reflective e-instruction, instructional design, digital library service system, open instructional design digital library.

\section{Introduction}

Education seems to be one of the most vibrant domains of social activity during the last decades worldwide. There is an impressive fan of endeavors, projects, ideas and solutions to organize education, having in one extreme a strict Skinnerian conditioning and in the other a society without an institutionalized education. Furthermore, traditional university world with both academics and students enjoying the intellectual challenge of mastery of knowledge is not a reality anymore. The pressure of the quickly changing world has significantly modified this paradigm. Nowadays students juggle their university life by doing parallel studies of different subjects, by working in order to sustain financially their studies, or by performing other activities. Therefore, educators have to devise new 
attractive ways for reflective teaching and learning in order to keep their students close to the knowledge world, the only known way to a sound personal evolution.

Impressive development of information and communication technology makes it possible to establish new flexible frameworks for teaching and learning. Computer-based instruction, online or offline, which emerges as an increasingly significant part of the educational process (whether it is self-made or within a virtual classroom), provides for the implementation of these new frameworks and therefore for the construction of (virtual) educational systems organically integrated into global social systems within Information Society (Vladoiu, 2001a). Main education goal in this new e-context becomes to obtain the ability to acquire and make proper use of knowledge in the real world, in order to improve one's life.

These novel pedagogical paradigms and methods will have to be stored in various educational digital archives, together with many other instructional components (Eshlemann, 2000; Vladoiu, 2001a):

- prerequisites for educational applications;

- syllabi;

- e-courseware (various educational applications:

lecture, laboratory, assessment etc.);

- user's profile and history;

- virtual reality modules;
- support tools;

- modules for dynamic courseware's generation (according to learner needs and suitable pedagogical models);

- e-instruction standards;

- learning management systems.

Such an archive can be seen as a dedicated instructional Digital Library (DL), which can be integrated in digital libraries that are more general. Consequently, it becomes available to anyone, anywhere, anytime, and with significant cost-savings. We consider that only an instructional digital library can provide for the availability and re-use of the instructional components to all interested instructional agents (human, software). In this paper, we introduce our development solution for the construction of a core instructional design digital library and for make it available to its possible users. The embedded model facilitates reflective learner-centered e-instruction.

We present firstly our model for instructional design of e-instruction, its support tool, and a construction scheme for storing this (evolving) model into a core instructional digital library, called OpenELib. We do that by using the services provided by an open digital library service system, named OpenDLib, which has been built at ISTI-CNR Pisa, Italy. We have chosen OpenDLib as a "constructor" for our instructional DL because it is open source, dynamically expandable with respect to content/services/usage, and because it has a powerful module for document representation.

Secondly, we introduce our research plan that approaches Instructional Design (ID) for reflective learner-centered (e-)instruction (we used brackets around "e-" to point out that we think some of the devised methods for ID for reflective learning, will work both for traditional teaching and learning process and for e-instruction; though, for clarity reasons will drop out on those further on). As main research objective, we have established the enhancement of the proposed ID model to incorporate practical ways to design e-instruction that facilitates reflective/transformational/critical learning by using appropriate combinations of behaviorist, cognitivist and constructivist elements, within collaborative frameworks. These ways could range from open engagement paradigms for 
e-lectures, e-learning sets/action e-learning activities, project/case-based e-learning, immersive complex e-instruction simulations, to engaged e-supervision and e-mentoring.

This work is to be done in three main stages:

1. Embedment of the proposed e-instruction model and of its support tools within a core instructional digital library built using the OpenDLib system.

2. Enhancement of the proposed model with instructional elements and methods that facilitate reflective e-instruction. This is to be done gradually as it is shown below:

- addition of conceptual elements for reflective instruction - that can be demonstrated as being viable in real-world instructional experiences;

- devising of practical ways to incorporate these elements in sample einstructional applications that are to be tested in various teaching and learning experiences;

- updating accordingly of the support tools and of the core instructional design digital library.

3. Disseminating constantly of the partial/final results through specific means.

We believe that this project has the potential to promote innovative contributions in the following directions summarized below:

$\Rightarrow$ providing instructional designers and educators with a valuable model for design of reflective e-instruction, with a methodology for its implementation (along with sample educational applications), and with its correspondent support tool. These will be stored in an open instructional design digital library available to anyone, anywhere, anytime, with significant cost savings;

$\Rightarrow$ proving that a digital library service system can enable different user communities to create and use their own digital libraries;

$\Rightarrow$ being a starting point for construction of a complete open instructional digital library that contains both instructional design elements and learning objects to be used for building sound instructional applications.

The results of the project work will be disseminated continuously in several ways presented below:

- Permanently developing, in parallel with the development and research activities, of the project website that will contain all the relevant results and a methodology for their practical use;

- Posting messages about current work significant progresses in important and active mailing lists for specialists in domains related to the proposal theme (as dbworld);

- Publishing research papers and presenting demonstrations to/in various scientific conferences and journals;

- Organization of workshops meant to familiarize specialists from education/academia with the model, its supporting tools and the use of the core instructional digital library.

This is ongoing work and currently we are developing the architecture of the core instructional design digital library and are dealing with the problem of representing all 
the documents that the support tool uses, according to the document model of the digital library constructor.

The paper is organized as follows: Section 2 is a brief overview of the content and capabilities of the instructional digital libraries available on the web (as a motivation for building another one!), Section 3 presents the ID model for e-instruction that we propose and the support tool (called DIP) that we have implemented accordingly, Section 4 shortly introduces OpenDLib, Section 5 describes how we can build the core instructional design DL by connecting the support tool DIP to OpenDLib, and Section 6 presents the possible enhancements for reflective learning. Finally, the last section lists some conclusions.

\section{Critical Overview of Instructional Digital Libraries Available on the Web}

Digital libraries that store learning objects have become appealing tools in the creation of various educational applications. Though, the instructional DLs that can be found on the web do not succesfully provide support for recombining and embedding discovered learning objects within new instruction paradigms and curricula. While significant progress has been made in the construction of DLs, there is still a lot to do for improving how learning objects are accessed/re-used and for enhancing support for design of instruction and for implementation of sound instructional systems (built according with viable instruction theories and best practice).

We have performed an extended investigation that concerns instructional digital libraries available on the web (presented in more detail elsewhere - Vladoiu, 2003a). During that we have found out that there are two classes of accessible instructional digital libraries: large initiatives that are continuously developing broad archives for many areas of arts, and sciences (including technical), and small particular DLs built as a support for specific purposes. From the former category we mention:

- SMETE that "opens up the worlds of science, mathematics, engineering and technology education to teachers and students anytime, anyplace" (SMETE, 2003);

- GEM which provides for "quick and easy access to thousands of educational resources found on various federal, state, university, non-profit, and commercial Internet sites" (GEM, 2003);

- MERLOT which is "a free, open resource designed primarily for higher education" (MERLOT, 2003);

- NEEDS that is a digital library of learning objects for engineering instruction (NEEDS, 2003);

- ERIC "that contains more than one million bibliographic records of journal articles, research reports, curriculum and teaching guides, conference papers, and books" (ERIC, 2003).

The later category contains many subject-oriented digital libraries as: Education Instructional Library - American Society for Microbiology, Pathology Education Instructional Resource, Teaching American History in Louisiana, Mathematical Sciences Digital Library - Mathematical Association of America, BIOME - a searchable catalogue of resources for health and life sciences etc.

Both kinds of DLs offer access (browse/search) to large collections of digital (hypermedia) documents (viewed as learning resources), but they provide little support for 
instructional design and for development of instructional systems. Thus, very few of them provide some links to sample curricula or to scientific papers about particular instruction issues.

The most prominent effort is ARIADNE (Alliance of Remote Instructional Authoring and Distribution Networks for Europe), a European suite of projects, which fashioned tools and methodologies for producing, managing and reusing computer-based pedagogical elements and telematics supported training curricula. This project had constructed a knowledge pool of instructional resources (learning objects, curricula etc.). Unfortunately, despite the fact that the project had built a valuable set of methodologies and support tools for all the actors involved in instruction, its results have not been used to their best potential and, consequently, the knowledge pool is rather poor. Simple searches for keywords like "memory", "cache", "round robin" for Operating Systems sub-domain, or "sort", "search", or "complexity" against Algorithmics sub-domain, had failed in founding any learning objects.

\section{A Model for Design of the e-Instructional Process and a Support Tool}

Knowledge is a fabric of relations in which one individual is fundamentally entwined with all others in a collective communication. Models help us to better understand and make sense of this knowledge. This is due to providing of means for comprehension of an, otherwise, incomprehensible problem. The traditional paradigm for instruction cannot be just shifted to the e-environment. Impressive development of information and communication technology makes it possible to establish new frameworks for teaching and learning. These new educational paradigms have to offer to learners opportunities for open worldwide lifelong instruction, to deal with various individualized quickly-changing (virtual) instructional environments, to provide access to various multiple sources of knowledge, and to improve the abilities of learners for self-initiated and reflective learning. An instructional design model gives structure and meaning to an instructional problem, enabling the would-be designer to negotiate her/his design task with a semblance of conscious understanding (Eshlemann, 2000). Models help us, in this case also, to visualize the problem, to break it down into discrete, manageable units.

Instructional design is the first step for building of complete instructional systems. Its outcome is an outline of the desired educational application, which can be directly implemented into a complete instructional package. This "blueprint" can consist of the named Educational Application (EdApp), lists of content resources, assumptions that limit the range/scope of the EdApp, knowledge and skills to be taught, the set of pinpointed behaviors necessary and relevant to the knowledge and skills to be taught, and the set of named units and modules, with each module containing a set of one or more behavioral objectives, each objective tagged and classified by learning category (Eshlemann, 2000).

We present here our proposed design model for the instructional process in an eenvironment. This model is extended and prescriptive. The extension concerns the part related to the e-instruction issues. It consists of the following stages: establishment of 


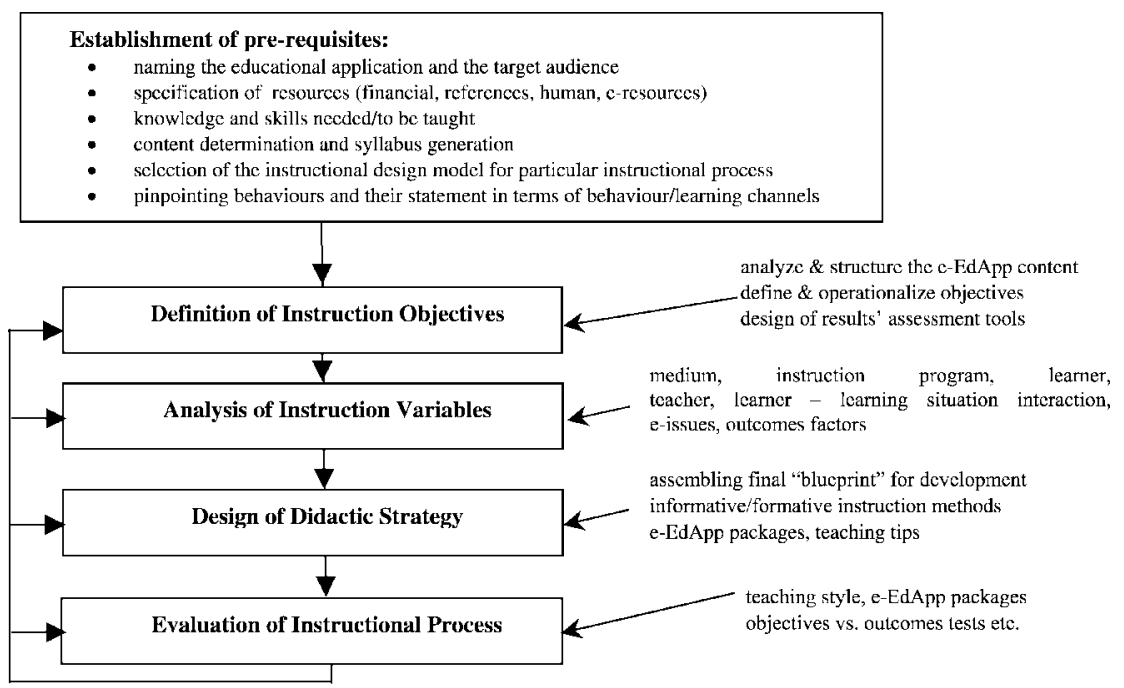

Fig. 1. Design of e-instruction.

pre-requisites, syllabus development, definition of instruction objectives, analysis of instruction variables, design of didactic strategy, and, finally, evaluation of the instructional process. It has been presented in more detail elsewhere (Vladoiu, 2003a). Here we introduce it briefly in the Fig. 1.

In order to support our model we have developed a software support tool, called DIP (Design of Instructional Process). This tool offers support to the instructional designers and educators. It provides for the settling of pre-requisites, definition of the behavior objectives that correspond to a given syllabus, analysis of the factors that influence the e-instruction process, design of an appropriate didactic strategy, and, finally, for evaluation of the characteristics/results of this process. Some capabilities of this integrated tool can provide (semi-) automated support for some parts of the traditional instructional process. The software package that implements DIP in Java 2 (from SUN), under Borland's JBuilder5, is quite simple and small sized (around 10000 source code lines). The graphical interface is simple and suggestive as it can be seen from Fig. 2.

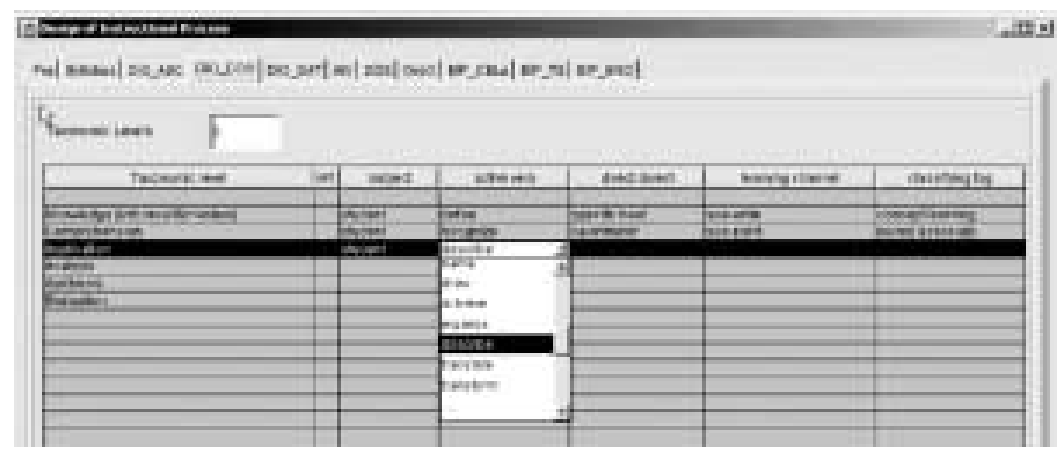

Fig. 2. DIP - a sample screen. 


\section{OpenDLib, a European Digital Library Service System}

OpenDLib is a Digital Library Service System (DLSS), which has been built at the DLib Center of ISTI-CNR from Pisa, Italy. Using this DLSS, a DL can be created by configuring and instantiating the system and either loading or gathering in the relevant digital document collection(s). OpenDLib is an open, distributed and dynamically expandable DLSS with respect to content, services and usage. OpenDLib provides a set of basic DL capabilities: acquisition, storage and preservation, search, browse and retrieval, selection and dissemination of documents, authorization and authentication of the users. Its architecture is that of a federation of interoperating services, which can be distributed/replicated on different servers. This set of services can be extended dynamically to provide additional functionality (Castelli and Pagano, 2002). The services support a powerful document model, called Document Model for Digital Library (DoMDL) (Castelli et al., 2002b), able to represent structured, multilingual and multimedia documents. DoMDL can be customized according to the structure of the digital content to be handled. Moreover, it permits the co-existence of multiple metadata records in different formats. All OpenDLib services are designed to support this flexible document model and its capabilities.

The OpenDLib system has been built as an open and networked federation of services. These services cooperate in order to implement OpenDLib functionality. This cooperation is more complex than a simple client-server application. A service can act both as a provider and as a consumer, and sharing relationships can exist beforehand among any subset of the services. Services, in fact, may be combined to support different functionality, and the same services may be used in different ways, depending on the restrictions and goal of sharing (Castelli and Pagano, 2003).

A digital libray system which runs OpenDLib usually includes multiple instances of the same service type that are hosted on remote servers of different organizations. Each service may require functionality from other services in order to solve its task. There are three classes of OpenDLib services. The first two, which have been called architectural infrastructure and basic utility services, implement the core functionality that is needed to support the third class of services, the application services. First release of OpenDLib supports a number of application services that implement the functionality of a conventional digital library (see below). Given the expandability of OpenDLib this set of services can be enhanced by adding more advanced services or services that serve the need of specific communities. All OpenDLib services of the first release are configurable. This provides a great flexibility that permits the use of the system for a variety of different DL application frameworks (Castelli and Pagano, 2003).

The application services implemented by the current OpenDLib release are as follows:

- Repository Service - which stores and disseminates documents that conform to DoMDL;

- Multimedia Storage Service - that supports the storage, the (real-time) streaming and the download delivery of the stored video manifestations of a document. Furthermore, it supports their dissemination either as whole documents or as aggregations of scenes, shots and frames; 
- Library Management Service supports the submission, withdrawal, and replacement of documents. It is configurable with respect to the metadata formats. Each of its instances can manage multiple metadata formats, helping the users to compile and submit them to the Repository;

- Index Service accepts queries and returns the documents that match those queries. The Index Service is parametric with respect to the metadata formats, to the set of indexed fields, to the set of result formats and to the language of the terms;

- Query Mediator Service which dispatches queries to appropriate Index Service instances;

- Browse Service that supports the construction of indexes for browsing and the actual browsing of these indexes on library contents. It is parametric with respect to the metadata formats, to the set of browsable fields, and to the set of formats for result sets;

- User Interface Service is a service, which mediates human interaction with the application services and their protocols. Each of the above services can be centralized, distributed or replicated. The configuration of the architecture, namely, which are the replicated services, how many are replicated, where they are hosted, etc, is decided when the DL is installed but can also be modified over the DL lifetime. The selection of the best architectural configuration is driven by contextual requirements, such as scalability, availability, privacy etc.

\section{Embedment of the e-Instruction Model within a Core Instructional DL}

The software tool that support the proposed ID model, which has been presented in a previous section, manipulates various kind of hypermedia documents that are involved in the design of the e-instructional process. These are listed below:

- documents that specify the pre-requsistes of the educational application to be built;

- files that contain the syllabi and the instructional materials;

- documents that include the operational objectives;

- file that contains the blueprint for the EdApp development;

- assessment files that help in the evaluation of e-instruction results and of the einstruction process itself;

- teaching tips files and so on.

In order to manipulate these files, we have thought that the best solution is the construction of an instructional design digital library (called OpenELib), using the services of the OpenDLib system. We have chosen OpenDLib as the builder of our ID digital library because it is open, expandable on-the-fly, open source and because it has a powerful document model, DoMDL, which is customizable and allows the use of multiple metadata formats. The easyness of adding new modules, in a plug-and-play manner is an important plus, in our view, given the challenging real-world situations the OpenELib digital library is supposed to deal with. 


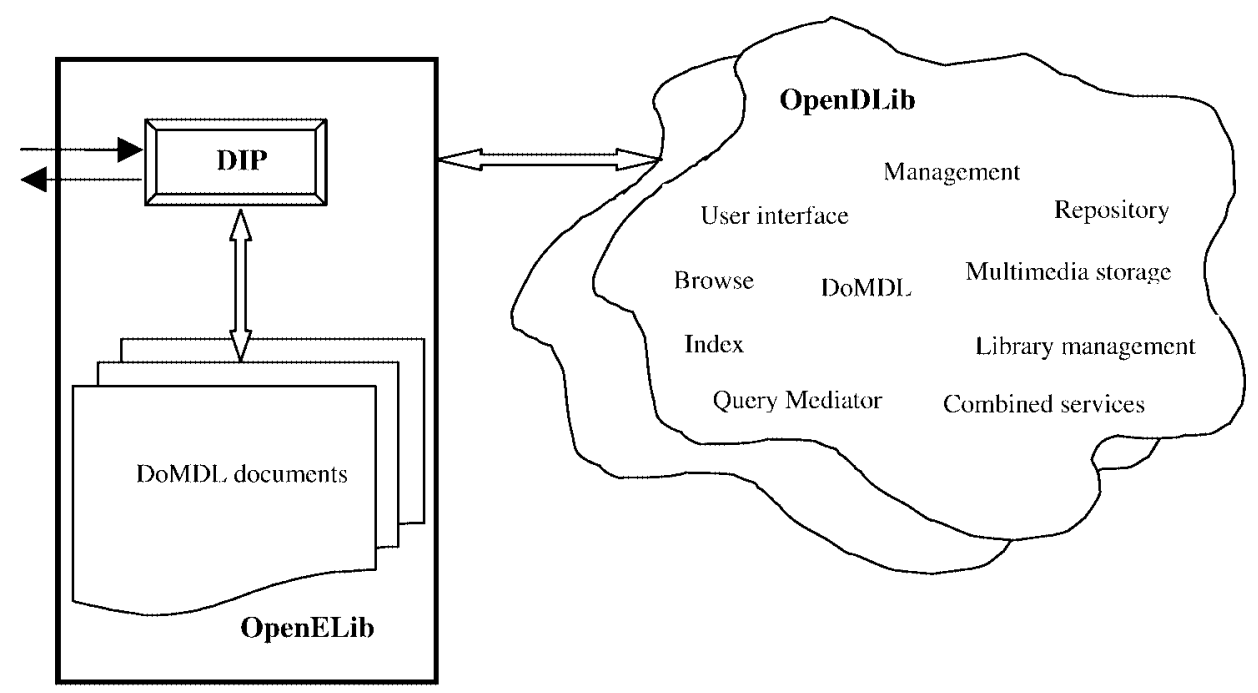

Fig. 3. Interaction OpenELib-OpenDLib.

This core instructional design digital library is meant to contain both the documents involved in the usage of the support tool and also DIP support tool itself, in order to make them available to their potential users. The documents manipulated by DIP are stored according to DoMDL. In Fig. 3 it is shown the OpenELib-OpenDLib interaction scheme that we have developed.

This development solution aims also to establish synergies with the ARIADNE system and to keep, if that can be done, the development work compatible, during the whole project life, with ARIADNE's achievements (e.g., Ariadne Curriculum Description Format, Ariadne's work in educational metadata). Thus, the project work can lead to the first open genuine instructional design digital library for reflective e-instruction worldwide, and can be the first step to the construction of a complete and consistent (European) open instructional digital library.

\section{Enhancement of the Proposed ID Model to Provide for Reflective e-Instruction}

The dominant issue in education nowadays is not access to more information. In fact, making sense of the huge quantity of material they are exposed to is a serious challenge for today learners. This, it is impossible to meaningfully digest and appropriate all the relevant information in even narrowest subject areas. Learning people waste huge amounts of time attempting to commit to memory concepts, facts, and procedures. Such memorization does not have a great impact on behavior and categorically does not translate into learned skills (Schank, 2002). In addition, many times, the expertise is unconscious and it has been obtained in years of practice and experience.

Under reflection perspective, the desired result of education becomes the construction of coherent functional knowledge structures adaptable to further lifelong learning. Re- 
flection can be seen both as a process by which an experience (thought, feeling, action) is brought into consideration (in- and following-action) and as a way to create meaning and conceptualization from that experience and to look back at it from another perspective (critical reflection), independently or in a social context. Learning contexts in almost all education forms are social constructs. Knowledge therefore is socially constructed. Essentially, the context of learning and what the learner perceives, consciously or not, as the ability to think, feel and act in any situation is crucial to the means by which that person becomes a reflective (transformational) learner (Brockbank and McGill, 1998; Light and Cox, 2001). Transformational or critical learning requires conditions that enable the learner to reflect upon her/his learning, not only by oneself but also along with others.

In the current stage of our OpenELib project, the foreseen research and development activities we intend to pursue are as follows:

$\triangleright$ Adding progressively the conceptual elements for reflective instruction that can be viable in real-world instructional experiences by using appropriate combinations of behaviorist, cognitivist and constructivist elements, within collaborative frameworks. The resulted e-instruction applications can vary from open engaging e-lectures, e-learning group activities, project/case-based e-learning, immersive complex e-simulations, to engaged e-supervision and e-mentoring.

$\triangleright$ Devising practical strategies and methods for adequate incorporation of valid reflective opportunities to e-instruction, and of the correspondent methodology;

$\triangleright$ Building some sample e-instructional applications according to the model, store them into the core instructional digital library, and testing them as such within real e-instructional experiences;

$\triangleright$ Updating OpenELib and the support tool according with the evolution of the conceptual model.

\section{Conclusions}

Our world - more precisely, our mental representation of the world - is continually becoming increasingly complex. New knowledge is added every day to the overall body of existing knowledge. We may say that knowledge is the new global asset - so people have to be constantly learning, devising innovative solutions to changing circumstances, staying informed and responsive. New developments in using information and communication technologies for education will probably have as much impact on this new millennium as the invention of Gutenberg's movable type press has had for the centuries that followed it. Not only communications will change in this "new age", but also our perceptual reaction to the world in which we live, our construct of reality, and the nature of knowledge. Education is emerging as the leader in the new order, but this does not necessarily mean traditional schools.

Given the socially constructed nature of knowledge and the fact that meaning is created in relation with others, reflection and creation of meaning are inevitably a social process. We create the conditions for critical reflective meaningful learning through reflective dialogue with others. Therefore, in order to have the learners (being they students 
or lifelong learners) managing the our present challenges, the only long-term solution seems to be the construction of educational e-environments in which they will not only learn, but they will learn to learn and to reflect on their learning process into a social e-context.

In this paper, we presented a development solution for building a core instructional design digital library for reflective learner-centered e-instruction and to make it available to its possible users, as a first step to reflective e-instruction.

In spite of our strong commitment to the need for building useful instructional digital libraries, we think that models and support tools can only provide valuable help in manipulating the elements of instructional design. Storing these within digital libraries will provide for coordination and reuse of instructional design elements (and for other instructional components as well), both by educators and learners. Nevertheless, instructional design of reflective e-instruction, even with e-support, will still be a very difficult task that cannot be automated completely. The main reason for this is its creative nature. Every educator has his/her own way to instruct and educate the learners. Having all the elements related to instruction stored into digital libraries, we will only have established the premises to let the educator to focus her/his energy and creativity on the main goal of education: sculpturing new personalities and guide them on their (future) way through life.

\section{Acknowledgements}

I would like to thank to ERCIM (European Research Consortium for Informatics and Mathematics) for awarding me the post-doc fellowship and for the constant support I have got from the people there, especially Ms. Emma Liere. It is my biggest pleasure to thank to Prof. Ingeborg Sølvberg, my supervisor there, at Department of Computer and Information Science (IDI), Norwegian University of Science and Technology (NTNU), for her kind support every step of the way, and to all people from IDI and NTNU for making me feel home there.

\section{References}

ARIADNE - European Foundation for the European Knowledge Pool (2003) http: / / www . ariadne-eu.org

Allesi, S.M.,and S.R. Trollip (2001). Multimedia for Learning. Methods and Development. Allyn and Bacon, Boston.

Bloom, B.S., and R.K. David (1956). Taxonomy of Educational Objectives: The Classification of Educational Goals, Handbook I: Cognitive Domain. Longmans-Green, New York.

Brockbank, A., and I. McGill (1998). Facilitating Reflective Learning in Higher Education. SRHE/Open University Press Imprint, Buckingham.

Castelli, D., and P. Pagano (2003). A system for building expandable digital libraries. In Proceedings of the Joint Conference on Digital Libraries (JCDL 2003).

Castelli, D., and P. Pagano (2002). OpenDLib: a digital library service system. In Proceedings of the European Conference on Digital Libraries (ECDL 2002). pp. 292-308. 
Castelli, D., C. Meghini and P. Pagano (2002). Foundations of a multidimensional query language for digital libraries. In Proceedings of the European Conference on Digital Libraries (ECDL 2002). pp. 251-265.

ERIC - Educational Resources Information Center (2003). http: / / www.eric.ed.gov/

Educational Instructional Library - American Society for Microbiology (2003). http://www.asmusa.org/edusrc/library/

Eshlemann, J.W. (2000). Instructional design. members.aol.com/johneshleman/design.html

Garisson, D.R., and T. Anderson (2003). E-Learning in the 21st Century. Routledge Falmer, London.

GEM - Gateway to Educational Materials (2003). www. thegateway. org

Gros, B. et al. (1997). Instructional design and the authoring of multimedia and hypermedia systems: does a marriage make sense? Educational Technology, 37(1), 48-56.

Kearsley, G. (2002). The Theories of Learning and Instruction. tip.psychology.org/theories.html

Hoffman, B. (2003). Encyclopedia of Educational Technology. coe.sdsu.edu/eet/Admin/TOC/

Hricko, M. (2002). Design and Implementation of Web-Enabled Teaching Tools. PA, Info. Science Pub., Hershey.

Internet Resources in the Health and Life Sciences (2003). http: / / biome.ac.uk

Leask, M. (2001). Issues in Teaching Using ICT, Vol.: Issues in Subject Teaching Series. Routledge Falmer, London.

Light, G., and R. Cox (2001). Learning and Teaching in Higher Education. The Reflective Professional. Paul Chapman Publishing, London.

Loughran, J.J. (1996). Developing Reflective Practice. Learning about Teaching and Learning through Modelling. Falmer Press, London.

Loveless, A., and V. Ellis (2001). ICT, Pedagogy and the Curriculum: Subject to Change. Routledge Falmer, London.

Mathdl-Mathematical Sciences Digital Library (2003). http: / / www . mathdl.org/

Mergel, B. (1998). Instructional Design\&Learning Theory. www.usask.ca/education/people/mergel.htm

MERLOT-Multimedia Educational Resource for Learning and Online Teaching (2003). www. merlot.org

NEEDS - A Digital Library for Engineering Education (2003). http: / /www. needs.org/needs/index. jhtml

NLVIM - National Library of Virtual Interactive Mathematics (2002). matti.usu.edu

NSDL - National Science, Mathematics, Engineering, and Technology Digital Library (2002). www. nsdl. org

Newman, M. (2001). PEPBL: Methodology on Flanders Interaction Analysis. www.hebes.mdx.ac.uk/teac.pdf

Noveanu, E., D. Mihalca, A. Ionescu-Zanetti, D. Preoteasa (1983). Modele de Instruire Formativa la Disciplinele Fundamentale de Invatamint. Editura Didactica si Pedagogica, Bucuresti.

PEIR - Pathology Education Instructional Resource (2003). http: //peir.path.uab.edu/

Prensky, M. (2001). Digital Game-Based Learning. McGraw-Hill, New York.

Radu, I. (1991). Teorie si Practica in Evaluarea Eficientei Invatamintului. Ed. Didactica si Pedagogica, Bucuresti.

Rosenberg, M.J. (2001). E-Learning: Strategies for Delivering Knowledge in the Digital Age. McGraw-Hill, New York.

Ryder, M. (2002). Instructional Design Models. carbon.cudenver.edu/ mryder/itc_data/idmodels.html

Schank, R.C. (2002). Designing World Class e-Learning: how IBM, GE, Harvard Business School, and 
Columbia University are Succeeding at e-Learning. McGraw-Hill, New York.

Schunk, D.H., and B.J. Zimmerman (1998). Self-Regulated Learning - from Teaching to Self-Reflective Practice. Guilford Press, New York.

SMETE - Science, Math, Engineering and Technology Education (2003).

http: / / www. smete.org

Teaching American History in Louisiana (2003).

http://diglib.lsu.edu/TAH.nsf/Web/TAH

Thorne, K. (2003). Blended Learning - how to Integrate Online \& Traditional Learning. Kogan Page Ltd, London.

Vladoiu, M.-M. (2003a). Learning objects need badly instructional digital libraries support. Informatics in Education, 2(2), 1-25.

Vladoiu, M.-M. (2003b). A support tool for modeling the computer-based instructional process. In Proceedings of 6th Int. Conference on Computer Based Learning in Science (CBLIS 2003). Nicosia, Cyprus.

Vladoiu, M.-M., and B.I. Matenciuc-Antonescu (2003). Reflective learning in large companies - can it work? In GI-Edition Lecture Notes in Informatics (LNI) for 2nd International Conference on Information Systems Technology and its Applications (ISTA'2003). Kharkiv, Ukraine.

Vladoiu, M.-M., and C. Negoita (2003). Reflective blended methods for teaching and learning operating systems. In Proceedings of 2nd International RoEduNet Conference Networking in Education and Research. Iasi, Romania.

Vladoiu, M. (2001a). A virtual teaching and learning environment. In Proceedings of Computer Based Learning in Science Conference (CBLIS'01). Brno, The Czech Republic.

Vladoiu, M. (2001b). Planning, designing and evaluating hypermedia CBL/COL applications. In Proceedings of Computer Based Learning in Science Conference (CBLIS'01). Brno, The Czech Republic.

Vladoiu, M. et al. (1997). Multimedia integrated model for active learning. In Proceedings of Computer Based Learning in Science Conference (CBLIS'97). Leicester, United Kingdom.

M.-M. Vladoiu got her MSc in the Department of Computer Science of Polytechnic University of Bucharest, Romania, in 1991. Since then, she has been with the Department of Informatics, PG University of Ploiesti (UPG), Romania, now being an assistant professor there. In 2002, she had got her doctoral degree in multimedia databases, with a thesis about a new multimedia object model. During the PhD work, she had the opportunity to specialize in object-oriented databases at University of Magdeburg, within the TEMPUS program framework (1998). In 2002, she had also been awarded with an ERCIM (European Research Consortium for Informatics and Mathematics) post-doctoral fellowship, to be carried on at Department of Computer and Information Science, Norwegian University of Science and Technology, Trondheim, Norway. Her main research interests are e-learning, instructional digital libraries, and reflective e-instruction. 


\title{
Atvirojo teksto skaitmeninės bibliotekos projektavimas - priemonė reflektyviam elektroniniam mokymui
}

\author{
Mihaela-Monica VLADOIU
}

Kompiuteriu pagristas mokymas (computer-based instruction), tiek dirbant tiesiogiai prisijungus prie kompiuteriu tinklo, tiek netiesiogiai, brèžia naujas ir paslankias pedagogines ribas, suteikiančias progą pasaulyje paplitusiam, visą gyvenimą trunkančiam mokymuisi igyvendinti. Visam tam talkina elektroninio mokymo koncepcija, apie kurią bus kalbama toliau.

Straipsnyje irodinejjama mokomuju programų kaupimo skaitmeninėse bibliotekose svarba tam, kad bet kas, bet kuriuo metu ir bet kurioje vietoje galetu jomis pasinaudoti. Kuriant skaitmenines bibliotekas i prieki pažengta pakankamai toli, tačiau vis dar nemažai vietos palikta gerinti mokomuju objektu pritaikomuma tiek mokytoju, tiek besimokančiuju reikmėms, tobulinti mokomuju programu dizaino kokybę bei taikyti garsines mokomąsias sistemas.

Straipsnyje pristatomas vykdomas projektas, kuriuo siekiama sukurti mokomosios skaitmeninès bibliotekos pagrinda, skirtą reflektyvioms, besimokančiojo reikmėms pritaikytoms elektroninems mokymo programoms bei padaryti šią biblioteką prieinamą visiems potencialiems vartotojams. Pirmiausia aprašomas savitas elektroniniu mokymo priemoniu kūrimo modelis bei jo palaikymo priemonès. Toliau supažindinama su schema, nusakančia, kaip ši plettojama modelį įtraukti į skaitmeninę biblioteką naudojant atvirojo teksto skaitmeninès bibliotekos sistemą „OpenDLib“, kurią sukūré ISTI-CNR Pizoje (Italija). „OpenDLib“ konstrukcija skaitmeninei bibliotekai kurti pasirinkta todèl, kad ši sistema turi galingą dokumentini modeli, taip pat yra atvirojo teksto, dinamiška ir nemokama. Straipsnio pabaigoje pristatomas tyrimu planas, skirtas mokomajam modeliui, palengvinančiam reflektyvu, besimokančiojo reikmèms pritaikytą elektronini mokymą. 